\title{
PAROTID FUNCTION TEST BY I31 CLEARANCE
}

\author{
By \\ S. NAKANO \\ From the Department of Otorhinolaryngology, School of Medicine, \\ Chiba University (Director: Prof. T. Kitamura)
}

I131 Clearance test were performed in 6 different groups of patients.

(1). There was hypofunction of the parotid gland in 14 cases of Xerostomia in a narrow sense. Sialogram on 12 of these cases revealed that hypofunction was due to extra-glandular factors in 3 cases, and intra-glandular factors in 6 cases.

(2) Examinations of 9 cases of acute parotitis revealed marked decrease or disapperance of the glandular function in all the cases. In chronic parotitis, hypofunction of the gland was not always demonstrated. It seemed like that function of the gland was depended upon the function of the unaffected portion of the gland.

(3) The glandular function was within normal limits in 8 cases of mixed tumour of the parotid gland and 3 cases of Mikulicz's disease. There was marked hypofunction of the gland in 2 cases of granuloma and lymphogranuloma.

(4) Following parotidectomy performed on one side, mild compensatory hyperfunction was observed on the other side in 8 out 11 cases examined.

(5) Hypofunction of the parotid gland was demonstrated in the majority of 10 cases of possible impairment of the parasympathetic secretory nerve in the tympanic cavity following to radical mastoid operation or chronic middle ear infection,

(6) The effect of $\mathrm{X}$-ray radiation to the parotid gland was studied in 17 cases. Complete loss of parotid function was observed in those who were thought to had been exposed to more than $5000 \mathrm{r}$ of X-ray,

(7) Biopsy of the parotid gland was compared with $I^{131}$ clearance in 17 cases. It was revealed that the results of $I^{131}$ clearance test were parallel to the intensity of histologic changes in the acini, and that the changes in the ductal system and striated tubules as well as the presence of lipomatosis had no influence on the results of the clearance test.

\section{$\mathrm{I}^{131}$ クリアランス法による耳下腺機能検查について 一その臨床的研究—}

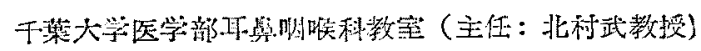

明手中虫野清幸
目次
A. 口内乾爆应 (Xerostomiasis)
去光当
次
B. 耳一下腺炎藏:
C. 耳下腺随晹
D. 片側耳下腺挍络洌

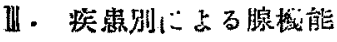
E. 分泌神経侵就洌

I. 榆柤方法

I . 検查成繶の判定 


\section{F. 放射線照射洌}

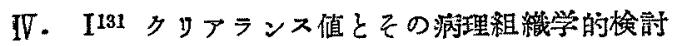

V・総括並に結編 交献

\section{まえがき}

唾夜腺機能々追究した臨床的研究恃蒾だ少く，負荷 ヨ

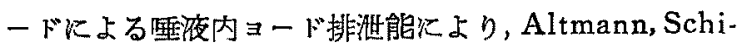
mansky，浅井が，又䑶液含有物貿の分析から腺機能壳 追究した業嫧として，ロダン定量そ Glasscheib, Alexander-Reko, Muck, Jürgens が, 無機成分炕ついて青 木が，物理的性状を勝田が報告しているに過ぎない，し かるこれら方潜は腺譏能を把握する上でな拓不充分の憾 みがあり又その成續も報告者炕より相当の幅があり，こ $\checkmark$ に腺機能を追究する上に機能とのるのを表現する動的 な検查方法が望まれる訳であるが，先に奥田が発表した 放射性同位元素 I'11 用いての I'131 タリアランス法は 上述の如き従来の方法とは全く異つた観点より出発し， 多くの基礎的検討を経て臨床上用い得へき検查方法と思 われるので，わたくしは以下述べる如き臨床㬰呀定行い 與味むる知見を得たのでこつ火報告し，諸賢の御批判を 仰ぎたい。

\section{I. 検查方法}

検查対象は食事による西夜腺の影響を避けるため全て 術前 4 時間絶食安静にさせた。文検查の目的及び内容を よく理解せしめ, 精神的不安, 恐怖感からの中枢性の分 泌抑制定極力避けるよ5に努めた・梌查中この意昧で適 当な新聞，雑誌を閲覧せしめた。

I $1311.5 \mu \mathrm{c} / \mathrm{kg}$ を20\%ブドー桾液に混和し，約 10 分 を費して極めて徐々に肘静脈より注入, 注入後適当の太 さのビニール管 (内径 $1.0 \mathrm{~mm} \times 10 \mathrm{~cm}$ 前後) をステ， ン氏管汇挿入し，整らくその機城的刺践の去るのをを ら，静注開始後 30 分上り酒石酸刺战による睡液家先に 揖入せるビニール管を介して目盛付スビッッグラスに 採取した・刺㦸に用いた酒石酸は1/8乞几浱度を10分 間隔 3 回, $1 / 4$ モ几濃度を 10 分間隔 3 回を夫な $1 \mathrm{cc}$ 宛 舌上に平等に撒布した。夫ふを1/8モルー，及び1/4モ

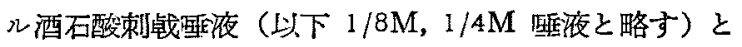
し, 刺战開始後 15 分，45 分に夫を反測の时静脈より約 $5 \mathrm{cc}$ を採血し，その血獎を検查に使用した。

上記 $1 / 8 \mathrm{M}$ 及び $1 / 4 \mathrm{M}$ 重夜の分必量（30 分）を測 定後, 充分振湯混和し夫ふの $0.1 \mathrm{cc}$ を, 又分離した

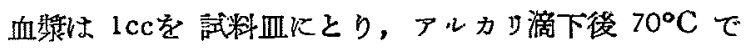
乾燥し直らに GM 管(神戸工業製)で测定した・クリ
アランス偲の算出は下式による。

$$
\mathrm{Cl}=\frac{\mathrm{S} \times \mathrm{V}}{\mathrm{P}}
$$

$\mathrm{Cl}:$ クリアランス值

$\mathrm{S}: 1 / 8 \mathrm{M}$ 文は $1 / 4 \mathrm{M}$ 垂液内 $\mathrm{I}^{131}(\mathrm{cpm} / \mathrm{cc})$

$\mathrm{V}$ ：喠液分泌量 $(\mathrm{cc} / \mathrm{min}$ )

$P$ ：血將内 $I^{131}(\mathrm{cpm} / \mathrm{cc})$

\section{II. 検査成樍の判定}

先に奥田は当検査法の基礎的研究に和いて，牦液腺正 常者の耳下腺クリアランス值を測定し表 1 の如き結果を 得ている.

表 1. 正常者のタリアランス值

\begin{tabular}{|c|c|c|c|c|c|}
\hline & & \multicolumn{2}{|c|}{ 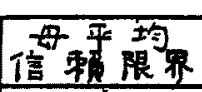 } & \multicolumn{2}{|c|}{ 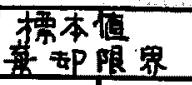 } \\
\hline & 平均值 & 下 $P_{2}$ & 上限 & 下 限 & 上限 \\
\hline 多Mつ唒 & 8.14 & 6.50 & 9.78 & 2.19 & 14.09 \\
\hline $1 / 4 M \supset$ 殖 & 7.11 & 6.32 & 7.90 & 4.22 & 10.00 \\
\hline
\end{tabular}

このクリアランス值からわたくしは下表の如き基準で $1 / 8$ 几酒石酸刺㦸クリアランス值（以下 $1 / 8 \mathrm{M}$ 值 と略す）及び $1 / 4 \mathrm{M}$ ク值を判定し，更にそのいられか に異常を認めるものを異常として，機能低下例 (一), 機能低下责疑へるるの (干), 正常例 (0), 機能六進の 疑へるもの（士），機能克進例 (十) の5 段階に分ち判 定した。
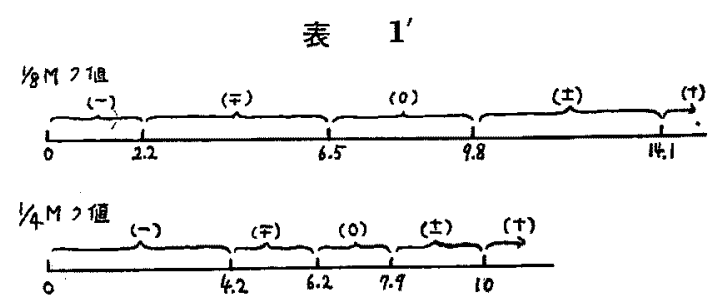

な打 I131 クリアランス法実施後，少くとす24時間経

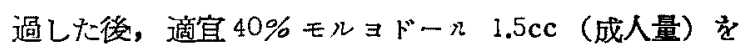
ステノン氏管を介して注入し，垂夜腺造影像（以下飳影 像之略す）をつくり北村の分類汇良い腺陰影を正常型

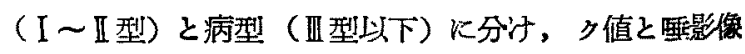
とを比較検討して腺機能を判定した。

\section{II1. 疾患別による眿機能}

A. 口内乾燥症 (Xerostomiasis)

1888 年 Hadden, Rowland, Harkin が野腹分淁の 抑制により生ずる口内乾煤症を報告してより，かつる症 
候群娄 Xerostomia なる名称に総括して幾多の報告が 見られる. (Seifert, Seeger, Curschmann, Chamberlin, Schmidthuber, Glasscheib，金杉，北村）

口内乾燥店が全身性疾患（例へば熱性疾患，急性下 痢, 粭尿病など)により萑起されることは古くより知ら れているが，か」る全身性疾患の一分定ではなく整夜分 些が何等かの原因で障碍され，これによつて持続的な口 内乾燥症が生ずる時，これる狭義の Xerostomia と云 ラベきであり，わたくしも対象をかつる症例佷定して 桧索した. この場合, Chamberlin, Glasscheib の述 へてている如く腺の慢性炎症の過程，あるい注流腺管の 閉塞などによつてもロ内乾燥症は起り得る訳であるが, これらは二次的に生じたるのですり，その原因疾患恃診 断するに比輘的容易であり, 従つてかつる症例はこの項 の検查対象からは除外した。

量夜分谜の減少から萑起される臨床症状としては，口 腔咽頭の乾懆感の他に異物感, 異和感, 粘稠感, 嶼下障 宫，発声困難など多彩な主訴として患者は訴へる。

わたくしは当科を訪れたこれら主訴を有する患者の 肉, 局所の炎店, 器貿的異常, 異物, 腫昜等は除外し, しかも全身性疾患の一分应であないこと確かめ，且既

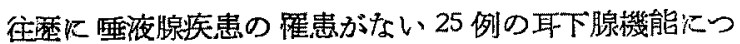
いて捡索した。これら患者を更に口腔咽頭粘膜に明らか 飞乾燥を認めるもの一A 群と，しからさるるの B 群 に分活た。

1. A 群: 一

表2 に示す如く 14 名（24才〜64才，男性 5, 女性 9) そついてのクッアランス值及び唾影像さ表の通りであ 尚.

即与機能 (一) 9 側，（干）10 側，（0） 2 側，（士） 2 側，（+）1側で検查全例 24 側中 9 側化機能低下を認め たに過ぎない。

次に $1 / 8 \mathrm{M}$ ク值, $1 / 4 \mathrm{M}$ ク值夫々の平均値と正常者 の平均値々の標本平均の検定を行つた所， $1 / 8 \mathrm{M} ク$ 值平 均值は 4.77 , 母平均 $3.52 \leqq \mathrm{~m} \leqq 6.02, \mathrm{Fs}=\frac{\mathrm{u}_{1}{ }^{2}}{\mathrm{u}_{2^{2}}{ }^{2}}=1.308$ $<\mathrm{F}_{99^{11}}{ }^{11}(0.05)$ となり両者の母分散等しく，その母平 均の検定では $\operatorname{Pr}\left\{\mathrm{t}_{\mathrm{s}}>\mathrm{t}\right\}=0.01$ となり有意羑をるつて本 群 よ正常者より低下值を示した. 又 $1 / 4 \mathrm{M}$ ク值平均值依 -5.77 , 母平均 $4.46 \leqq \mathrm{~m} \leqq 7.08, \mathrm{Fs}=\frac{\mathbf{u}_{\mathbf{1}^{2}}}{\mathrm{u}_{2}{ }^{2}}=4.524>\mathrm{F}^{\mathbf{1}_{23}}$ (0.05) 々なり母分散は等しからず，その母平均の検定 では近似阡算で危険率 5\%で有意差をもつて本群のク值 甠低下值を示した。

表 2. A 群

\begin{tabular}{|c|c|c|c|c|c|c|}
\hline & & & 717 & 天㖇 & 栈 & \\
\hline No. & EA & 年. 性 & $V_{8} M$ & $1 / 4 M$ & 能 & \\
\hline 1 & M.G. & 54 ㅇ & $\begin{array}{l}3.0 \\
01.5\end{array}$ & 6.9 & $\begin{array}{l}(\overline{7}) \\
(-)\end{array}$ & TV \\
\hline 2 & N.A. & $24 \checkmark$ & $\begin{array}{r}02.0 \\
0.7\end{array}$ & $\begin{array}{l}2.3 \\
3.6\end{array}$ & $\begin{array}{l}(-) \\
(-)\end{array}$ & $I$ \\
\hline 3 & W. Y. & 547 & $\begin{array}{r}7.6 \\
10.0\end{array}$ & $\begin{array}{l}12.3 \\
13.6\end{array}$ & $\begin{array}{l}(0) \\
(T)\end{array}$ & III \\
\hline 4 & K.K. & $46 \%$ & $\begin{array}{r}5.7 \\
04.6 \\
\end{array}$ & $\begin{array}{l}5.7 \\
6.4 \\
\end{array}$ & $\begin{array}{l}(F) \\
(F)\end{array}$ & TV \\
\hline 5 & A. T. & 499 & $\begin{array}{r}02.0 \\
3.7\end{array}$ & $\begin{array}{l}4.2 \\
2.8\end{array}$ & $\begin{array}{l}(-) \\
(-)\end{array}$ & $\nabla$ \\
\hline 6 & T. M. & 419 & $\begin{array}{l}5.2 \\
3.7\end{array}$ & $\begin{array}{l}4.1 \\
3.4\end{array}$ & $\begin{array}{l}(-) \\
(-)\end{array}$ & \\
\hline 7 & K.J. & 575 & 5.4 & 5.4 & (F) & III \\
\hline 8 & H.K. & 449 & 3.3 & 6.4 & (₹) & \\
\hline 9 & M.Y. & $54 \hbar$ & $\begin{array}{r}04.2 \\
4.9\end{array}$ & $\begin{array}{l}3.5 \\
4.4\end{array}$ & $\begin{array}{l}(\vec{E}) \\
(\bar{F})\end{array}$ & $I$ \\
\hline 10 & K. T. & $45 \%$ & 0 & 0 & $(-)$ & IX \\
\hline 11 & S.M. & $27 q$ & $\begin{array}{r}03.6 \\
4.6\end{array}$ & $\begin{array}{l}5.6 \\
7.0\end{array}$ & $\begin{array}{l}(\bar{f}) \\
(\bar{F})\end{array}$ & III \\
\hline 12 & S.F. & $32 \tau$ & $\begin{array}{r}4.7 \\
04.8\end{array}$ & $\begin{array}{l}5.0 \\
4.9\end{array}$ & $\begin{array}{l}(\bar{F}) \\
(\bar{f})\end{array}$ & $I$ \\
\hline 13 & T. T. & $69 \hat{b}$ & $\begin{array}{r}010.3 \\
11.9\end{array}$ & $\begin{array}{r}7.4 \\
10.7 \\
\end{array}$ & $\begin{array}{l}(I) \\
(I)\end{array}$ & $\nabla_{2}$ \\
\hline 14 & Y.M. & 559 & 7.3 & 8.5 & $(0)$ & III \\
\hline
\end{tabular}

○印棰影法を行つた側を示す

更にこの群に特ける性別と年令との問題では 40 才以 下男性 2 , 女性 1 に対し 40 才以上では男性 3 , 女性 9 を 示し，比較的高年令の女性徒症例の $64 \%$ を占めて和引， Hadden, Curschmann 等の指摘していること〉一致し ている.

表 3. A 群

\begin{tabular}{|c|c|c|}
\hline 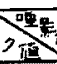 & $=$ & 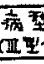 \\
\hline$(-)$ & 2 & 2 \\
\hline$(\bar{F})$ & 1 & 4 \\
\hline$(0)$ & 0 & 2 \\
\hline$( \pm)$ & 0 & 1 \\
\hline$(t)$ & 0 & 0 \\
\hline
\end{tabular}

\section{B 群: 一}

口腔咽頭粘膜に他覚的乾燥状態著明ならざる 17 例 (18 才〜1 才，男性 7，女性 10）についての成績法 4 の
次にこの群に郝ける睡影法堂行 つた12 例についてその棰影像と ク値を比較検討してみると（表3） 機能（一）及び（干）9例中 6 例 が腺の組織学的変化を表現する俥 影像炕拈いて病型（四型以下）を 示しこれに反し機能の低下示 した拘らず眰影像が正常型を示 したものは3例であった。 
表 4. B 碓

\begin{tabular}{|c|c|c|c|c|c|c|}
\hline No & E甘 & 年性 & \begin{tabular}{|l|}
$247^{3}$ \\
$48 M$ \\
\end{tabular} & $\frac{\pi}{4 M}$ & $\begin{array}{l}\text { 棧 } \\
\text { 能 }\end{array}$ & 噃影依 \\
\hline 1. & N.K. & $48 \hat{\delta}$ & $\begin{array}{l}10.1 \\
12.3\end{array}$ & $\begin{array}{l}7.4 \\
8.0\end{array}$ & $\begin{array}{l}\text { (t) } \\
\text { (t) }\end{array}$ & J. 2 \\
\hline 2 & I.J. & $27{ }^{\circ}$ & $\begin{array}{r}5.3 \\
9.2\end{array}$ & $\begin{array}{l}6.3 \\
8.2\end{array}$ & $\begin{array}{l}(0) \\
(0)\end{array}$ & $I$ \\
\hline 3 & M.A. & 269 & $\begin{array}{r}12.0 \\
011.9\end{array}$ & $\begin{array}{r}8.9 \\
10.2\end{array}$ & $\begin{array}{l}\text { (I) } \\
( \pm)\end{array}$ & II \\
\hline 4 & T. K. & 649 & 12.7 & 8.5 & (स) & $I$ \\
\hline 5 & o.k. & 189 & $\begin{array}{l}6.4 \\
0 \\
0.9 \\
\end{array}$ & $\begin{array}{l}8.1 \\
5.9 \\
\end{array}$ & $\begin{array}{l}(0) \\
(0) \\
\end{array}$ & II \\
\hline 6 & M.Y. & $26 \$$ & $\begin{array}{r}012.2 \\
8.4\end{array}$ & $\begin{array}{l}7.1 \\
5.9\end{array}$ & $\begin{array}{l}(0) \\
(0)\end{array}$ & I \\
\hline 7 & J.N. & $57 t$ & $\begin{array}{r}05.6 \\
4.1 \\
\end{array}$ & $\begin{array}{l}5.5 \\
4.7 \\
\end{array}$ & $\begin{array}{l}\text { (F) } \\
\text { (F) }\end{array}$ & I \\
\hline 8 & S.S. & $69^{\circ}$ & $\begin{array}{r}8.5 \\
5.3 \\
\end{array}$ & $\begin{array}{l}8.8 \\
8.5 \\
\end{array}$ & $\begin{array}{l}\text { (0) } \\
\text { (o) }\end{array}$ & $I$ \\
\hline 9 & N.Y. & $7 / 5$ & \begin{tabular}{|l|}
13.2 \\
10.3 \\
\end{tabular} & $\begin{array}{r}8.9 \\
12.4 \\
\end{array}$ & $\begin{array}{l}(t) \\
(t) \\
\end{array}$ & \\
\hline 10 & A.H. & 255 & $\begin{array}{r}06.7 \\
10.5 \\
\end{array}$ & $\begin{array}{l}7.5 \\
9.2 \\
\end{array}$ & $\begin{array}{l}(0) \\
( \pm)\end{array}$ & I \\
\hline 11 & Y.N. & $38 \%$ & $\begin{array}{r}0 \\
11.4 \\
14.4 \\
\end{array}$ & $\begin{array}{l}10.3 \\
13.2 \\
\end{array}$ & $\begin{array}{l}\text { (t) } \\
(t) \\
\end{array}$ & II \\
\hline 12 & S.D. & $6 / 5$ & 9.2 & 5.9 & (0) & $I$ \\
\hline 13 & 0.1 . & 319 & $\begin{array}{l}7.1 \\
7.4 \\
\end{array}$ & $\begin{array}{r}10.4 \\
8.3 \\
\end{array}$ & $\begin{array}{l}(0) \\
(0) \\
\end{array}$ & 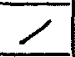 \\
\hline 14 & S.T. & 379 & $\begin{array}{r}06.9 \\
6.7 \\
\end{array}$ & $\begin{array}{l}6.6 \\
6.0 \\
\end{array}$ & $\begin{array}{l}0) \\
(0) \\
\end{array}$ & I \\
\hline 15 & S.Y. & 439 & $\begin{array}{r}15.0 \\
010.2 \\
\end{array}$ & $\begin{array}{l}7.8 \\
7.0 \\
\end{array}$ & $\begin{array}{l}\text { (4) } \\
(0)\end{array}$ & I \\
\hline 16 & $\mathrm{H} . \mathrm{H}$. & 439 & 14.4 & 11.7 & $(t)$ & III \\
\hline 17 & A.M. & 407 & $\begin{array}{r}0.2 \\
6.1\end{array}$ & $\begin{array}{l}6.2 \\
5.1\end{array}$ & $\begin{array}{l}(7) \\
(7)\end{array}$ & II \\
\hline
\end{tabular}

○印业影法を行つた側を示す。

如くである.その性別反び 年令は 40 才以下男性 3，女 性 5，41 寸以上男性 4, 女性 5 で A 群浔認められた如 き特異性仕喼められなからた。腺機能 (干) 4 側，（） 14 側，（士）9側!（+）4側で機能（一）の子のは 1 例 る認められなからた。

この群の推計学的処理では $1 / 8 \mathrm{M}$ ク値平均值 9.30, 母平均 $8.16 \leqq \mathrm{~m} \leqq 10.44, \mathrm{Fs}=\frac{\mathrm{u}_{1}{ }^{2}}{\mathrm{u}_{2}{ }^{2}}=1.347<\mathrm{F}^{11_{30}}(0.05)$ となり正常者群との母分散任等しく，正常者群の母平均 との検定は $\operatorname{Pr}\left\{\mathrm{t}_{i}>\mathrm{t}\right\}=0.2$ となり仵険率 $5 \%$ では有意 差は認められず，一方 $1 / 4 \mathrm{M}$ 名值では平均值 8.04 , 母 平均 $7.27 \leqq \mathrm{~m} \leqq 8.81, \mathrm{Fs}_{\mathrm{s}}=\frac{\mathrm{u}_{2}{ }^{2}}{\mathrm{u}_{2}{ }^{2}}=2.570>\mathrm{F}_{30}(0.05)$ となり正常者群の母分散と等しく，表 $\mathbf{5}$. B 群 母平均の検定では $\operatorname{Pr}\left\{\mathrm{t}_{\mathrm{s}}>\mathrm{t}\right\}=0.2$ となり，危除率 $5 \%$ で佂正常者と の間に有意差恰認められなからた。

次に睡影像を行い得た 15 例に ついてそのク值と比較検討してみ ると（表5）タ值，影像とも正 常例 7 例, 機能 (干), 雷影像正
常型 2 例，譏能 (土)，眐影像正常型 5 例で，15 例中 14 例虫罣影像正常で 且機能も正常範囲にあることを認 めた.

Xerostomia 快比較的高年令の女性火多いと云われ (Curschmann, Hadden) そ程稀疾患ではいとさ れているが，Curschmannの29才男性火生した報告例 の如く若年者汇も起り得る。しかし乍らその本態は単一 でなく，Curschmann はこれを 1).老人性㢣縮，2）精 神的因子，3）中枢性障得に分讨，又 Schmidthuber， Glasscheib は idiopatish (腺の慢性炎症の過程, 管系 の閉塞) 飞 symptomatisch (神絟性中枢性障碍) 飞に 分け，Furstenberg は 1) 精神恎，2）腺組䅧の崩壊灯 よるむの，3）神絰性に分類し，更に単一の俥液腺の組

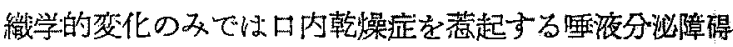
は起り慕いことから神経性機序の障碍を重視しており， Seeger は植物神経性の变調を強調している，他方 $\mathrm{Ch}$ a mberlin 经画液腺よりの膿汗排泄完た症例飞起つた Xerostomia 報告している. 北村は Xerostomia い 原因学局所的原因と分泌神経匴碍と儿大別し，更湔者

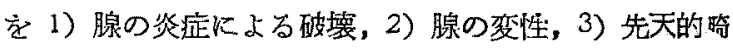

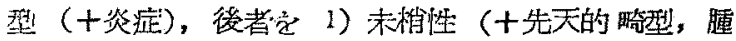

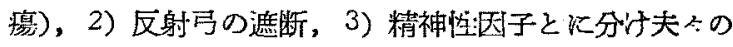
症例学報告している。

本群に和ける検查対象は前述した如く，腺の炎症，渏 型，腫境は除外し又検查に際し恐怖页は不安より起る精 神性の因子は努めて除くようにしたので，A 群に和け るク值が低く且つ病型の棰影像を示した6例（No. 1, $4,5,7,10,11$ ) は腺自体に変化のあるため㟟起された

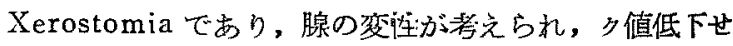

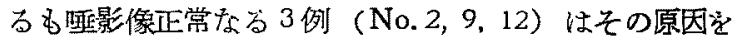
分泌神絰の異常に求をべざ，反射弓の遮断によるもの

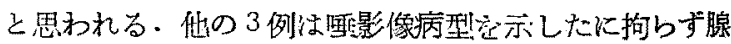
袎能儿低下完見ふかつたが，ある゙限界以下の筫的乃至量

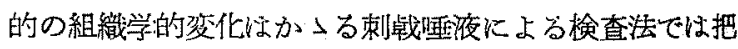
握し得ないためと思和れる。

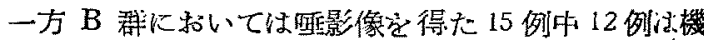
能正常又は機能直進の疑へるもので，これらはいつれす 正常型の喠影像定示している．往つて本群の症例の大多 数标腺機能も正常で且つ腺組織にも障碍が認めっれない ことから主訴の由来す兮原因㤔俅むい゙きでる。そ の他機能低下を疑へるク値る示し且つ喠影像の正常なる 2 例炕ついてはA 群の分汹神経異常の 軽度のものと思 わ礼合。 
B. 耳下腺の炎症

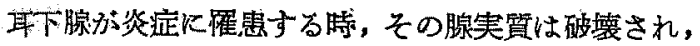

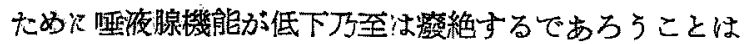
容易こ想像される。乎実前項儿执いて述べた如く Chamberlin, Glasscheib 恬耳下腺焱㶤起因す Xerost○ mia を報告しており，又 Schimansky は唾㖡腺の急 泩炎淀に際して腺構造の破壊に伴うてその機能る低下し ていることをヨード排㴹試験で証明している・わたくし

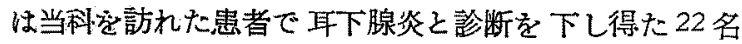
にっいて、これを急性焱症群と慢性炎症群とに分行て I ${ }^{1.11}$ クリアランス法を契施し以下の成績觉得た。

\section{1. 急性炎症}

急性炎症洋 9 例 10 側（9才〜75才）のタ值注表6に ぶす如く機能（一）9側，（干）1 側で殊に $1 / 8 \mathrm{M}$ 万值

表 6. 急性炎柾

\begin{tabular}{|c|c|c|c|c|c|}
\hline No. & 氏名 & 年性 & $\frac{311 P^{3}}{\frac{18 M}{18}}$ & $\frac{2 \sqrt{12}}{4 M}$ & 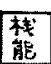 \\
\hline 1 & O.F. & 76 & 2.3 & 3.2 & \\
\hline 2 & S.Y. & $14 \hbar$ & 2.4 & 1.9 & \\
\hline 3 & O.H. & 169 & 2.2 & 2.6 & $(-)$ \\
\hline 4 & T.Y. & $20 \%$ & 5.4 & 5.1 & $(-)$ \\
\hline 5 & N-M. & $26 \checkmark$ & $\begin{array}{l}6.6 \\
4.9\end{array}$ & $\begin{array}{l}4.8 \\
3.3\end{array}$ & $\left.\begin{array}{c}(F) \\
(-)\end{array}\right)$ \\
\hline 6 & K.S. & 30 今 & 0.8 & 3.2 & $\leftrightarrow$ \\
\hline 7 & S.H. & $53 \%$ & 0 & 0 & $(-)$ \\
\hline 8 & S.T. & 659 & 0 & 0.3 & $\Leftrightarrow$ \\
\hline 9 & K.T. & 759 & 0 & & $c-$ \\
\hline
\end{tabular}

の污が $1 / 4 \mathrm{M}$ ク值よりも正常值に近く $1 / 4 \mathrm{M}$ 酒石酸剢 践に至つてク值の急䜿を示するのが 5 例に認められたこ と腺実質の破㯖を示しているものと思われる。

2. 慢性炎症

慢性炎症群 13 例 15 侧では腺機能 (一) 6 侧，（干）6 側, （士）1 側，（+）2 側であった（表 7）この群で機 能が必しる低下を示さなかつたのは资症䍜患部の状態の みでなく残存腺部の態度が機能を左右する因子となつて いるためと思われる.このことは西影像で特異な所見て 呈する Swinburne の云う整液管掖張症 (Sialoangiektasis 表 7 の印）でも6 例中機能低下を示したのは 2例のみであるのはその唾影像からみて奇異の感を抱か せるが，次に述べる如く残存腺部力態度がかつるク值の 変動となつて現われたるのと思われる. 即ち Siloangieltasis 住中年の女性に多いと云われているが若年者の
表 7. 慢性资是

\begin{tabular}{|c|c|c|c|c|c|}
\hline No. & 囘名 & 年性 & 3195 & 酮 & $\begin{array}{l}\text { 裓 } \\
\text { 能 }\end{array}$ \\
\hline 1 & A.G. & 85 & 8.8 & 3.6 & $(-)$ \\
\hline 2 & D.K. & $10 f$ & 7.4 & 5.8 & $(\mp)$ \\
\hline 3 & H.S. & 105 & 1.2 & 2.9 & $(-)$ \\
\hline 4 & D.K. & 199 & $\begin{array}{l}1.4 \\
0.8\end{array}$ & $\begin{array}{l}1.1 \\
0.9\end{array}$ & $\begin{array}{l}(-) \\
(-)\end{array}$ \\
\hline 5 & T.S. & $22 \%$ & 8.5 & 5.4 & $(F)$ \\
\hline 6 & S.S. & 419 & 0 & 0 & $(-)$ \\
\hline 7 & Y.T. & 449 & $\begin{array}{l}5.4 \\
4.5\end{array}$ & $\begin{array}{l}5.6 \\
4.5\end{array}$ & $\left(\begin{array}{l}(F) \\
(\mp)\end{array}\right.$ \\
\hline A 8 & Y.N. & $50 \%$ & 14.1 & 12.1 & $(t)$ \\
\hline 9 & A.H. & 539 & 7.3 & 9.1 & $(I)$ \\
\hline 10 & M.K. & 559 & 0 & 7.3 & $(-)$ \\
\hline 11 & H.T. & 557 & 4.0 & 4.3 & (F) \\
\hline 12 & I.K. & 576 & 7.4 & 5.5 & $(\mp)$ \\
\hline 13 & T. T. & 578 & 7.9 & 13.4 & $(t)$ \\
\hline
\end{tabular}

報告も見られており，その病因以ついては多くの病理学: 者は慢性炎症に原因を求めているが，Bailey の如く先 天説をとつているるのむある，Godwin はこの状態を benign lymphoeptithelial lesion と定㼁して批り炎症 説に左組している，その病理祖織学的所見では，管から 由来した上皮細胞で被われた散在した病巣を含むりンパ 組織の集団からなり，腺終部讨存在するが容易に破壊 される (Bisgard-Kimball, Godwin).かつる上皮で 被われた腔の生成に関してい多くの学者により意見が 分れ，Bailey は先天的畹型説を，Bisgard-Kimball, Jones は拨張説をとるのに対して，北村は先天的渏型の 他江上皮の状態から周囲組織の萎緶伦々の成因を求めて いる・がる内腔の存在が反復する感染の原因であるこ とは指摘されているところで、これらが度重なるにつれ 周囲の残存腺部住逐次荒家汇帰して行くのであるが，か

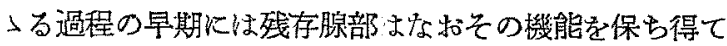
比較的正常な機能の表現示するのと思われ，かつる症 例の垂影像老観察すると点状陰影の間に腺実質の陰影を 認めることからも理解できる。

\section{C. 耳下腺腄場}

耳下腺に発生する腫痦况混合腫癔が圧倒的に多いとさ れており，その統計的観察でる耳下腺堙瘍の 70〜90\% を占めるとされている. (宮地, 松島) わたくしは.8〜 68

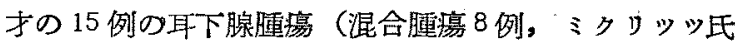
病 3 例, 肉芽嗹, 淋巴肉芽腫, 腺連, 腺癌各 1 例) 飞つ 
表 8. 耳下腺盾湯

\begin{tabular}{|c|c|c|c|c|c|c|}
\hline No. & F5 & 年 性 & & 21125 & 资值 & 䟵 \\
\hline & & & & & & \\
\hline 1 & K.N. & $56 \hat{\jmath}$ & 毗合脭㿋 & 14.5 & 14.3 & $(t)$ \\
\hline 2 & A. $k$. & $35 q$ & 今 上 & 9,0 & 6.4 & (0) \\
\hline 3 & T. K. & $31 \delta$ & 全上 & 7.3 & 7.8 & (0) \\
\hline 4 & $S . M$. & $46 \%$ & 今上 & 8.2 & 6.1 & (0) \\
\hline 5 & N.O. & $36 \$$ & 今上 & 5.2 & 7.2 & (0) \\
\hline 6 & S.K. & 28 ㅇ & 令上 & 2.1 & 5.7 & $(-)$ \\
\hline 7 & D. S & 480 & 全上 & 10.7 & 14.1 & (t) \\
\hline 8 & I.D. & $21 \%$ & 今上 & 8.6 & 11.5 & (I) \\
\hline 9 & S.I, & 561 & ミフリッ"ノに病 & & $\begin{array}{l}9.7 \\
6.3\end{array}$ & $\begin{array}{l}(I) \\
(0)\end{array}$ \\
\hline 10 & K.H. & $8 \hat{b}$ & 今 上 & $\begin{array}{l}12.0 \\
11.4\end{array}$ & $\begin{array}{l}8.7 \\
10.0\end{array}$ & $\begin{array}{l}\text { (I) } \\
\text { (I) }\end{array}$ \\
\hline 11 & K.S. & 53 우 & 今 上 & 9.5 & 6.3 & $(0)$ \\
\hline 12 & O.S. & 509 & 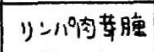 & $\begin{array}{l}0 \\
0\end{array}$ & $\begin{array}{l}0 \\
0\end{array}$ & $\left(\begin{array}{l}(-) \\
(-)\end{array}\right.$ \\
\hline 13 & T.S. & 259 & 肉芽佺 & 3.6 & 2.6 & $(-)$ \\
\hline 14 & H.T. & $32 \hbar$ & 腺 脏 & 4.5 & 4.7 & $(F)$ \\
\hline 15 & S.K. & 685 & 月里 㴔 & 7.1 & 4.7 & $(\mp)$ \\
\hline
\end{tabular}

いての耳下腺機能を検索した（表 8). いつれも手術万 至は試験切除による病理組織学的診断を下し得た例であ る.一方耳下腺腫瘍の重夜乃至は腺機能についての研究 は甚だ少く, 本邦で勝田, 青木が耳下腺垂液の物理的, 化学的性状を報告しているに過ざない.

わたくしの検查した耳下腺混合腄瘍 8 例 (男性 3, 女 性 5) では禨能（0） 4 例，（土）1例，(十）2例，(-) 1 例であつた。混合腫瘍は組織学的には結合織被膜によ り腺突貿とは明膫に境され所謂良性腰愓に属する。従つ て梌查成縉が大部分正常機能若しくは軽度の克進を示し たのはかつる組織学的性状から残存腺部が充分機能を遂 行し得えためと思われる。このことは残存腺部の重影像 が低下值を示した 1 例を除いては正常型であることから も理解できる。低下值を示した1例ではその残存腺部の 唾影像は而型を示し，その組織像も Lipomatosis が著 明で且つ腺細胞の萎縮も誋められ，ためにかつるク值を 示したものと思われる、か子る変化が腫湯から由来した ものか否かは軽々しく判定できないが, この症例におい ては区側のク值も $1 / 8 \mathrm{M} 1.5,1 / 4 \mathrm{M} 6.1$ と低下值を示 しているので腫瘍による影響以外の低下值と見るべきで

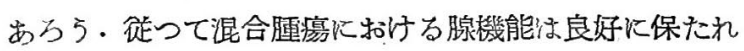
ていると云つて差支ないと思われる・

1892 年 Mikulicz により報告された畄液腺及び涙腺
の無痛性腫脹はミクリッッ氏病又は症候群と名付けら れ，その本態に関して大きな反響を呼び多数例が報告さ れているが，現在では Schaffer 及び Jacobson の分 類した如く病变が涙腺及び 唾液腺のみに限局している 㮦，これをミクリッッ氏病と呼び，全身病の部分症状と して現われている場合をミタリッッ氏症候群としてい る.しかし作らミクリッッ氏病の場合に挌いて子然の現 われ方は種々であり，その本態についても多くの説が挙 げられているが，最近 Neuss はアレルギー説と共に系 統的疾患（例へば Sjögren 氏病, Heerfordt 氏病） との関連性を強調している.病理組織学的には小円形細 胞の浸潤, 腺実質の萎縮, 結合織の增殖が挙げられ,こ れらが種々な程度に組合つており，又これにェオジノフ ヘリーを認めることがある・北村及び布施は組織学的所 見より，小円形細胞の増県著明で組織エオジノフィリー 文び結合織増殖の認められないI型（所謂 Mikulicz's disease proper) と小円形細胞の浸潤は蹯で組織エォジ ノフィリー及び結合織增殖の著明な II 型を分け，II型に

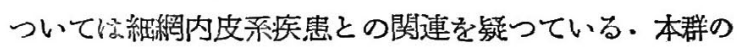
3 例は上記分類に従うと I 型 2, II 型 1 例であるが共に 耳下腺機能には低下認めなかつた。これらは夫そ上述 の如き特異な組織像を呈する以外の腺実質はな打保持さ れて抽のためにからるク值を示していると考へられ む (写真 1$)$.

真写 1. ミクリッッ氏病 (耳下腺)

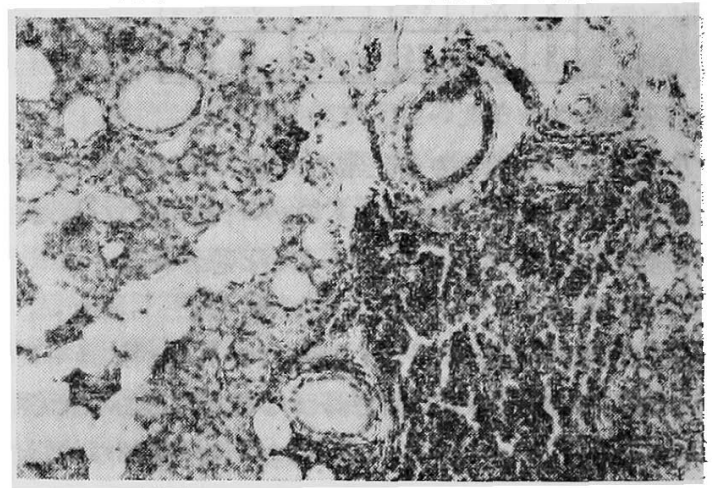

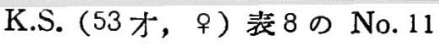

これに反し淋巴肉芽腫及び肉芽腫の 2 例ではその病理 組織学的所見は共に腺実質が高度に破壊され殆んど残存 腺部が認められず，従つてかつるク値を示したと思われ る (写真 2 ).

腺腫及び腺癌の各 1 例は夫々機能低下を矛へるク值を 示して和り両者共その残存腺部の重影像は病型を示し た。 
写真 2. 淋巴肉芽媑 (耳下腺)

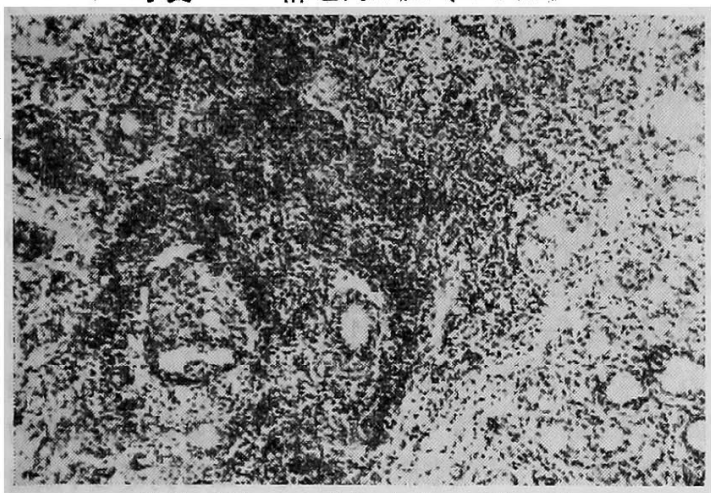

O.S. (50才, 古) 注 8 の No. 12

\section{D. 片側耳下腺萿出}

動物実験において重夜腺を摘出して他画夜腺に及ぼす 影響を顴察した報告はあるが（土屋 1924，赤崎 1933） 臨床上耳下腺片側摘出後残存耳下腺についての機能の砳 究は, 教室の勝田, 青木が 重夜の物理的乃至化学的性 質の分析から特に機能に变化のないことを報告している のみである・おたくしは表9 亿示す如き片側耳下腺摘出

表 9. 片側耳-下腺摘出冽

\begin{tabular}{|c|c|c|c|c|c|c|c|}
\hline No. & Es & 年令 & $\frac{5197}{\frac{519}{4}}$ & $\frac{-\pi \sqrt{1}}{y_{4} M}$ & $\begin{array}{l}\text { 垡 } \\
\text { 能 }\end{array}$ & 桁后 & 姑影破 \\
\hline 1 & H.T. & 43 우 & 0 & 2.7 & $(-)$ & 2月 & III \\
\hline 2 & T.R. & 349 & 8.5 & 9.9 & (I) & 4月 & I \\
\hline 3 & Н.Т. & 189 & 8.2 & 9.9 & $(I)$ & 5月 & I \\
\hline 4 & T.R. & 349 & 11.9 & 9.8 & $( \pm)$ & 5月 & I \\
\hline 5 & S.M. & .469 & 10.7 & 8.6 & $( \pm)$ & 6月 & II \\
\hline 6 & T. A. & $14 \delta$ & 9.5 & 7.3 & $(0)$. & 7月 & II \\
\hline 7 & I. H. & 569 & 7.4 & 9.3 & (t) & 10月 & I \\
\hline 8 & $A, K$. & 195 & 4.0 & 6.0 & $(\mp)$ & | 年 & II \\
\hline 9 & K.J. & 446 & 6.7 & 9.0 & $( \pm)$ & $1.5 \frac{5}{4}$ & $I$ \\
\hline 10 & A.T. & 309 & 6.4 & 2.9 & $(-)$ & 2 年 & II \\
\hline$! 1$ & k.k. & 609 & 13.4 & 8.7 & $( \pm)$ & 3. 年 & I \\
\hline
\end{tabular}

後の残存耳下腺 11 例（術後経過年数 2 ケ月～3 年）に ついて I131 クリアランス法を実施し次の如き成綪を得 た,

即ち，11 例中機能（一) 2 例，(干) 1 例，(0) 1 例, （土）７例を認めた，整影像は機能（一）の1例のみが 病型（型）を示した他は全例とも正常型であつた。

この内ク値が $1 / 8 \mathrm{M}, 1 / 4 \mathrm{M}$ 共正常範囲にあると思わ れる9例について，推計的処理を施すと $1 / 8 \mathrm{M}$ ク值で
は平均值 8.89 , 母平均 $6.14 \leqq \mathrm{~m} \leqq 11.64$, 正常人の平均值 の比較検定では， $\mathrm{Fs}=\frac{\mathrm{u}_{2}{ }^{2}}{\mathrm{u}_{1}{ }^{2}}=1.07<\mathrm{F}_{7}{ }^{8}(0.05)$ そなり 両者の母分散は等しいが，その母平均の検定では $\operatorname{Pr}\left\{\mathrm{t}_{\mathrm{s}}>\mathrm{t}\right\}=0.7$ で正常人との間に有意差は認められない が, $1 / 4 \mathrm{M}$ ク值では平均值 8.94 , 母平均 $7.78 \leqq \mathrm{~m} \leqq 10.10$, 正常人の平均值の比較検定では $\mathrm{Fs}=\frac{\mathrm{u}_{1}{ }^{2}}{\mathrm{u}_{2}{ }^{2}}=1.44<\mathrm{F}^{2} \mathrm{~s}$ （0.05）となり母分散は等しく，その母平均の㭘定では $\operatorname{Pr}\left\{t_{\mathrm{s}}>\mathrm{t}\right\}=0.05$ となり正常人との間隹意差をもつて 高值を示した。即ら残存耳下腺の大部分法軽度の代償性 機能充進を示していると云へる.

\section{E. 分必神経:侵蟹例}

耳下腺垂夜分泌の副交感性径路は，脳幹に達した刺㦸 が下唾夜核に至り,こつから節前線維として舌咽神経, 鼓索枝, 鼓室神経丵, 小浅岩神経を経て耳神経節に至 ク,こつから節後線維が耳下線に至る・一方交感神経系 としては脊䯑道の前根と共に走る上胸白枝を経て上頸神経 節に至る節前線維と, こつから耳下腺に至る節後線維と からなつている.

耳下腺で副交感神経が刺㦸されると稀涾な水分の多い 分泌が起るが，交感神経のみの刺㦸でけ認もべき分必心 起らない (Furstenberg). 又, Cl. Bernard, Heidenhaim, Langley により発見された副交感性分泌神経切! 断後に生ずる麻痺性分泌峏顎下腺沉起り,耳下腺では見 られないとされている(林, 古川，富田）。

耳下腺に至る副交感性分泌神経は上記の経過中, 鼓室 に病変乃至は侵警が加はつた場合分泌神経が障碍され， 従つて耳下腺機能が底下するであらうことは容易に想像 される所である、Muck は急性, 慢性中耳炎の耳下腺 哩液についてロダン含有量の減少乃至沈除を認めてい るが, Altmann は11 名の中耳根治手術の際の堇夜腺機 能を沃度を負荷しその排泄能より顎下，舌下腺について 検討し左右差を認めて括らずこれを節後線維の二次的恢 復に帰しているが, 浅井は中耳根治手術の際の耳下腺機 能を検查し沃度排泄量の減少を認めこれを鼓室内副交感 神経性分泌神経の障碍に基ら゙くと考へている。

わたくしは表 10 亿示寸如き 10 例 11 側(15 オ〜59才) についてその耳下腺 I ${ }^{131}$ クリアランス法を行い以下゙の 成績を得た。

即ち, 機能 (一) 4 側, (干) 3 側, (0) 3 側，（士） 1 侧である.これらのク值は相当にバラつき，1つの集団 として推計的処理を加へることは無理と思はれる。然し 
表 10. 分泌神経侵䫓冽

\begin{tabular}{|c|c|c|c|c|c|c|}
\hline No. & 民务 & 年 性 & $\frac{7175}{\frac{718 M}{18}}$ & $\frac{x^{2 \pi}}{V_{4} M}$ & \begin{tabular}{|l|} 
戔 \\
能 \\
\end{tabular} & 借 考 \\
\hline 1 & M.N. & 85 & $\begin{array}{l}0.3 \\
6.4 \\
\end{array}$ & $\begin{array}{l}7.4 \\
6.1\end{array}$ & $(0)$ & 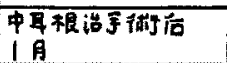 \\
\hline 2 & $0 . \mathrm{H.}$ & $15 \%$ & $\begin{array}{r}11.7 \\
0 \quad 1.7\end{array}$ & $\begin{array}{l}10.9 \\
0.6\end{array}$ & $(\rightarrow)$ & 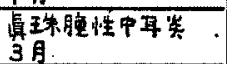 \\
\hline 3 & N.M. & $15 q$ & $\begin{array}{r}5.6 \\
03.7 \\
\end{array}$ & $\begin{array}{l}6.0 \\
4.1 \\
\end{array}$ & $(\rightarrow)$ & 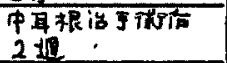 \\
\hline 4 & D.S. & 165 & $\begin{array}{r}0.8 \\
0 \quad 1.9\end{array}$ & $\begin{array}{l}7.4 \\
3.7\end{array}$ & 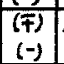 & 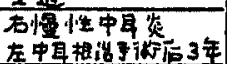 \\
\hline 5 & k.k. & $17 t$ & $\begin{array}{r}05.4 \\
11.9 \\
\end{array}$ & $\begin{array}{l}4.1 \\
4.9 \\
\end{array}$ & $(-)$ & 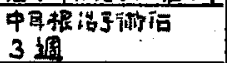 \\
\hline 6 & H.E. & 225 & $\begin{array}{r}10.9 \\
13.5\end{array}$ & $\begin{array}{l}10.4 \\
12.6\end{array}$ & (I) & 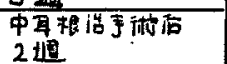 \\
\hline 7 & K.Z. & $27 \delta$ & $\begin{array}{r}2.7 \\
8.8 \\
\end{array}$ & $\begin{array}{r}6.7 \\
11.9 \\
\end{array}$ & $(\bar{F})$ & 外满性颜种施必。 \\
\hline 8 & W.s. & $45 t$ & $\begin{aligned} 07.6 \\
7.5 \\
\end{aligned}$ & $\begin{array}{l}7.5 \\
8.1\end{array}$ & (0) & 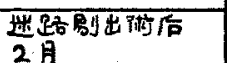 \\
\hline 9 & T.K. & $47 t$ & $\begin{array}{r}09.5 \\
12.7\end{array}$ & $\begin{array}{l}8.9 \\
9.6\end{array}$ & (0) & 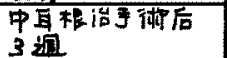 \\
\hline 10 & A.K. & 599 & $\begin{array}{r}09.8 \\
12.3 \\
\end{array}$ & $\begin{array}{l}4.7 \\
9.1\end{array}$ & (F) & 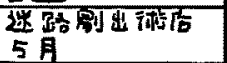 \\
\hline
\end{tabular}

OFi 患

㑡

て鼓室内分泌神経障碍が，予想された如き結果を示した のは11 側中 7 側の過半数に認められたが，璔予期に反 したク值を示するの4側をみた。このことは，Altmann の云 5 節後線維の二次的恢復の他侸室内での侵警程度 の差が考へらるべきである。

\section{F. 放射線照射例}

橅液腺のレ線照射による機能の变化は，Schmidt が 疑告して以来 Porders, Mühlmann 等の報告があり， 本邦でる都筑，横須賀，比企，村上等によりレ線炤射後 の西液腺組維の变化についての実験的研究があり，又村 上往実験的研究の結論より人耳下腺慣の治療には少量䀡 射では一眰分泌扣制炕成功するも再び分泌機転量生ずる ことから比較的大量昭射を推罢している. 又 Schiman-

表 11. 放射楾照射洌

\begin{tabular}{|c|c|c|c|c|c|c|c|c|c|c|}
\hline No. & 民名 & 每性 & \begin{tabular}{|l|}
$2 y \overline{P I}$ \\
$18 M$
\end{tabular} & $\frac{2 \pi}{144}$ & \begin{tabular}{|l} 
整 \\
烈
\end{tabular} & 病 & 照的部位 & 線量 & 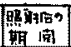 & 等影谣 \\
\hline 1 & K.T. & 381 & ? & $\begin{array}{l}4.2 \\
6.7\end{array}$ & $\left(\begin{array}{l}-1 \\
(-)\end{array}\right.$ & 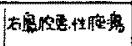 & 石程部 210 & $\begin{array}{l}\mathrm{Co}^{60} \\
6000 \mathrm{r}\end{array}$ & 24 時 & $\pi$ \\
\hline 2 & S.H. & $32 q$ & कर & 13.6 & $(t)$ & 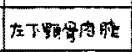 & 左下累 & $\begin{array}{l}\mathrm{Co}^{60} \\
5500 \mathrm{r}\end{array}$ & 1月 & II \\
\hline 3 & $0 . Y$. & 618 & $\begin{array}{l}0 \\
0\end{array}$ & 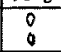 & $\begin{array}{l}i-1 \\
a \rightarrow\end{array}$ & 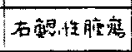 & 石到部 & \begin{tabular}{|l|} 
\\
$6 \mathrm{coor}$
\end{tabular} & 4月 & $\mathbb{N}$ \\
\hline 4 & K.T. & 389 & $\begin{array}{l}(6) \\
10.3\end{array}$ & 13.7 & $(+)$ & 左再下腺密 & 在耳下部 & $\begin{array}{l}C^{60} \\
4200 \mathrm{P} \\
\end{array}$ & $4.5 \mathrm{~A}$ & I \\
\hline 5 & I. T. & 359 & $\begin{array}{c}(\bar{I}) \\
8.6 \\
\end{array}$ & 5.6 & $(\omega)$ & 右可下腰痤 & 右耳下部 & $\begin{array}{c}C 0^{60} \\
60009 \\
\end{array}$ & 5月 & I \\
\hline 6 & S.H. & 569 & $(x)$ & 0 & $(-)$ & 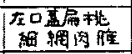 & 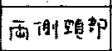 & 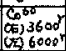 & 6月 & 昷 \\
\hline 7 & I. I. & $26 \%$ & $\begin{array}{l}(5) \\
7.1\end{array}$ & $\varepsilon .1$ & (0) & 左耳下膘掘 & 左再下部 & $\begin{array}{l}c^{660} \\
50000^{7}\end{array}$ & 8 月 & $I$ \\
\hline 8 & K.Y. & 709 & $:$ & $\begin{array}{l}0 \\
0\end{array}$ & $\begin{array}{l}(-) \\
(-)\end{array}$ & 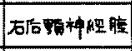 & 右锤部 & $\begin{array}{l}\text { Re. } 19464 \\
6570\end{array}$ & $1 \frac{4}{4}$ & 宜 \\
\hline 9 & S.K. & 735 & $\begin{array}{l}\text { (E) } \\
10.0\end{array}$ & 9.7 & (t) & 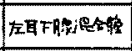 & 五引下部 & $\begin{array}{l}x \\
50004\end{array}$ & 1年 & $\zeta$ \\
\hline 10 & N.H. & 529 & $\begin{array}{r}15.3 \\
15.2 \\
\end{array}$ & $\begin{array}{l}74.1 \\
14.1\end{array}$ & $\begin{array}{c}(5) \\
(+)\end{array}$ & 下㯰䫄事 & 西恻埇部 & $\begin{array}{l}x \\
6000 r \\
\end{array}$ & $1.5 \frac{5}{4}$ & $I$ \\
\hline i. & H.M. & $7 / \hat{b}$ & $\begin{array}{l}7.2 \\
11.2 \\
\end{array}$ & $\begin{array}{l}7.3 \\
8.9 \\
\end{array}$ & $\begin{array}{l}0 \\
0 \\
0\end{array}$ & 喉酩癌 & 両何顆部 & $\begin{array}{l}x \\
4000 r\end{array}$ & 2.59 & $I$ \\
\hline 12 & $0 . \bar{Y}$ & 616 & $\begin{array}{l}(6) \\
8.8\end{array}$ & 10.0 & (0) & 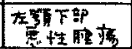 & 左路下部 & $\begin{array}{l}x \\
6000^{r}\end{array}$ & 2.5 年 & $I$ \\
\hline
\end{tabular}

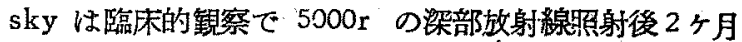

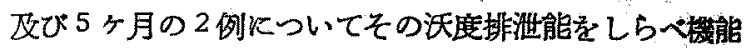
の廃絶報告している。

わたくしは当科入院中の患者で耳下腺に比較的大量の 放射線が昭射されたと思われる患者 12 例 17 側（26 ま

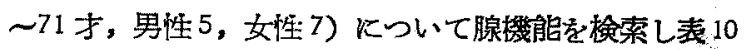
の如き結果を得た。

即ち機能 (-) 7 側, (0) 4 側, (土) 2 側, (t) 4 側 で西つた・一方垂影法を行い得た症例についてみると機 能低下例圢全て病型を示し機能低下が腺の病理組織学的 没化に由来したことを物語つている・正常例若しくは機

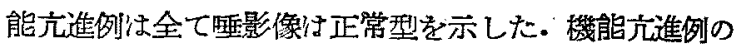
了例は過刺践の状熊にあつたためと思はれる，更にこれ らの成績を照射後の期間灭び検查対象となつた耳下腺の 被曝線量と併世考へてみると機能低下例 4 例の内 2 例忙 照射直後及び 4 ケ月の成領でありこれが永久的に機能低 下のま入推移するか:否かは疑門であるが，No.6，8は6 ケ月及び 1 年以上経過して和り而も対象耳下線には少く とも5000r. 以上の被曝が考克られるので，樑部治㞠火 より耳下腺機能が持綕的に廃絶を芫るのは相当大量の放 射線照射によつてのみ生ずると考へられる。

\section{I131 クリアランス值とその病理 組織学的検討}

先に奥田は大雷夜腺火炎症，異物舫入，深部放射線照 射，薬物中毒を実験的に萑起せしめてその組織像と $I^{131}$ クリアランス值との関連を追究し腺の萎紑变性汇従つて ク值の低下することを認めている。

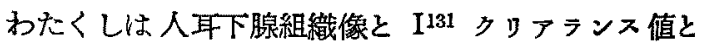
を比較検討してみた。

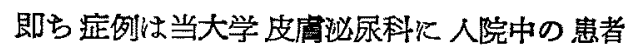
で,その耳下腺機能測定の依頼を5けたるので， 32 才〜2才の 12 例である。

型の如くI 131 クリアランス法を実施後，一両 日後に，下頡角部に小切開を扣き同部より耳下腺 の試験切除学行い，一次的に腺被膜及文び皮有を繾 合した・術後重夜亚等の不快な後遺症を残したも のは1 例となく又術創法下须にかくれて醜形を残 さない，唒組織像への影響を考へて術前の喠影法 汸行っていない。

その病理組織学的所見とク值とを示せば表 12 の如くである.

即ち 12 例中，機能 (一) 3 例，(干) 2 例，(0) 5 例, (十) 2 例であり, この内機能 (一)の子の 
表 12.

\begin{tabular}{|c|c|c|c|c|c|c|c|c|c|c|c|c|c|c|c|c|}
\hline No. & $a b$ & 性 & 点 & & & & & & & & & & 照 & $1 / 6 \mathrm{~m}$ & $\frac{x \times 4}{1 / 4 M}$ & $\begin{array}{l}n x \\
\text { 能 }\end{array}$ \\
\hline I. & S.E. & 315 & 背螕石 & + & - & - & $(t)$ & - & -1 & - & -1 & $(T)$ & \pm & 15.5 & 12.9 & \\
\hline 2. & N.M. & 329 & 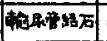 & (t) & $\begin{array}{l}\top \\
\end{array}$ & - & - & (t) & - & - & - & $(t)$ & + & 7.7 & 7.0 & (10) \\
\hline 3 & k. & $40 \%$ & 前上胜怔不 & + & + & - & - & - & - & (t) & - & - & (t) & 5.6 & 11.5 & \\
\hline 4. & H.T. & 575 & 前立䐂竞 & $t$ & (+) & - & $(t)$ & $=$ & - & - & - & $(\rightarrow)$ & - & 6.6 & 6.3 & \\
\hline 5 & $M \cdot K$. & 575 & 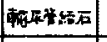 & + & (4) & - & + & - & - & - & + & - & 土 & 6.2 & 2.4 & 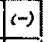 \\
\hline 6 & A.T. & $58 \hat{~}$ & 前立腈把大 & - & - & - & - & - & - & - & - & - & \pm & 9.8 & 10.5 & $(t)$ \\
\hline$\eta$ & I.S. & 609 & 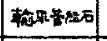 & + & + & - & + & t & - & - & \pm & - & + & 9.7 & 7.6 & $(0)$ \\
\hline 8 & H.E. & $62 t$ & 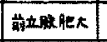 & $t$ & - & - & (t) & \pm & - & + & + & - & \pm & 7.4 & 3.3 & $(\rightarrow)$ \\
\hline 9 & Y.S. & 619 & 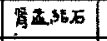 & + & - & - & - & (t) & - & + & + & (t) & + & 7.3 & 5.9 & $(F)$ \\
\hline 10 & O.H. & $63 \delta$ & 首立腊侣不 & $t$ & - & - & - & - & - & -1 & \# & (t) & + & 0 & 0 & $(-)$ \\
\hline 11 & T.M. & $72\}$ & 今 $上$ & + & + & - & - & - & - & (x) & - & $(+1)$ & - & 7.6 & 7.2 & (0) \\
\hline 12 & HiS. & $75 t$ & 今 & - & - & (t) & - & -1 & (t) & - & (t) & $(4)$ & - & 5.7 & 5.0 & $\langle F$ \\
\hline
\end{tabular}

且放射能測定:䒾置以外特殊な器具を必要としない こと䈏が 挙げられている(奥田). 然し乍らこの 㭘查方法は腺細胞の血中よりの $I^{132}$ 排泄洫が対 象となつているので矣患の性状と云うよりは腺機 能の程度を数量的に把握するものであり，従って 夜腺の臨床を問題とする埸合，腺白体の病理組 織学的表現である晓影法を保せ行つて機能異常が 腺内性のるのか腺外憔のるのが区別することが 必要である. Schimansky む負荷ョードによる

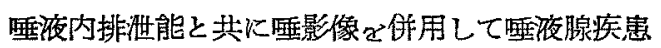
の解明そ試みている。

すたくしは I131 クリアランス法と筀影法と定 用ひ，臨床例としてロ内乾懆症他6君偣についての

は何れる腺部に萎縮像の強いもので，一方腺部の菱維が 部分的な症例ではク值怟下を示さず，残存腺部の代償 により機能は正常に保持されていると想像される. 文導 管の扇平化は大部分隹められているがこれがク值に值 接関連をるつとは思はれない。

機能过隹を示した 2 例については正常値をとつたもの との間注理租織学的に誌むべき相違はなく，恐らく過 刺战の結果と思はれる・更に条效部の変化は全例とも㪕 度文は変化なく，ク值との間に一定の閭係を見出し得な かつた. 㕛症例が上記の如く比較的高年令のものが多く 徙って Lipomatosis は種々の程度に認められたがこれ そク值との間に一定の関係を見出していない。

\section{V. 総括並に䊅論}

西液腺穖能検査法としては従来主として画液の分析か らその機能が推論されていたが，Zack, Altmann によ りョード負荷によるョードの棰液内排泄が検查されるに 及んで機能とのるのの動的把握が可能になつた．然し乍 らこの方法も定量的には不確実であり，出現時間も非常 に早期なのて捕捉に困難である・文排沭されたョードの

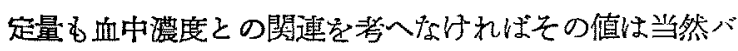
ラつく䇢である。

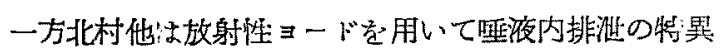

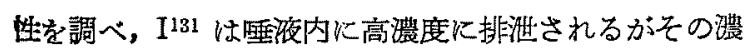

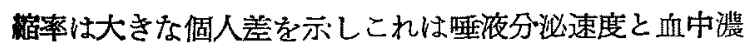
㿑と関連づけことにより一定となることを認めこ」 に I131 クリアシンス法が生れたのであるが，その特長 としては從来の検查方法と比較して 1) 值が安定である こと，2）主として奖腹腺細胞の機能を 対象としている こと，3）日时差，左右瑟なく，甲状腺機能，植物神経 桑，体重とは無関係であること，4）検宣方法が簡単で 耳下腺機能を追究し以下述べる如き結論を得た。即ち，

1) 口腔咽頭乾燥感, 粘揫感, 異物感, 啡下障碍, 発 声困難等の主訴を有し, 然も局所に器質的異常を認めな い症例で他覚的に口腔咽頭粘膜に乾懆を認める症候群で は明らかに耳下腺機能の低下を認め，更にこれらの原因 が腺の病理組䅧学的变化による埸合と分流神経系の遮断 による埸合とを鑑別した・かつる症例が真陮の Xerostomia に属すると思はれる。

2）耳下腺念性炎症群では著明な腺機能の但下乃至は 廃絶を認めた一方慢性炎症群では必しも機能は低下せ ず，その残存腙部の状態が腺譏能を左右するるのと思は れる。

3）耳下腺良胜腫揚, ミクリッッ氏病では腺機能に異 常は認めなかつた・これに反し淋巴肉芽腫及び肉芽䐺は 著明な機能低下を認めた。

4）片測耳下腺を摘出した場合，他側の残存耳下腺に は軽度の代償怪機能艺谁と認めた。

5）鼓室内に於方る耳下腺副交感神絟性分必神経が侵

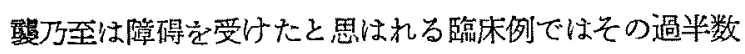
に機能低下家認めた。

6）耳下腺部に5000r 以上の放射線が照射された茄 合に持続的機能廃絶要認めた。

7）I131 クロアランス法による腺機能とその病理組織 学的所見の刘比では，ク值は腺部の状態に左台され，導 管部, 条繖部の変化及び Lipomatosis いことを認めた。

\section{主要参考文献}

1) Altmann, F. \& Löwy, B.: Arcb. Ohren usw. Hk. 134; 189, (1933). 2) Alexander, G. \& Reko, B.: Wien. Klin. Wschr. 59, (1902). 3) 淺非: 


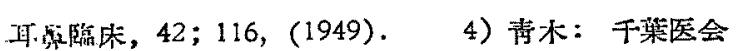
就, 33; 126, (1957). 5) Bailey, H.: J. Int. Coll. Surg. 8;109, (1945). 6) Bisgarä, D. \& Kimball, K.: Arch. Surg. 71; 337, (1955).

7) Chamberlin, W.: J.A.M.A. $95 ; 470$, (1930). 8) Curschmann, H.: Arch. Verdaunngskht. 18; 21, (1912). 9) Furstenberg, A.\& Crosby, E.: Ann. Oto. etc. 54 ; 243, (1945). 10) Glasscdeib, A.: Monatschr. f. Ohrenheilk. 64 ; 423, (1930). 11) Godwin, J.: Cancer 5 ; 1089, (1952). 12) Hadden, W.: Lancet 553, (1888). 13) Harkin, A.: Lancet 257，(1888). 14) 林他：日坐理雑誋，1；391, (1939). 15) 古川; 日生理醀誌，1；189，(1939). 16）比企：其京医会誌，47；772，(1933）.17）今

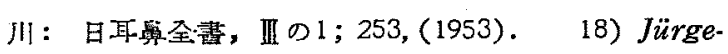
ns, E.: Monatschr. f. Ohrenheilk. 35 : (1905). 19) Jones, E.: Arch. Dis. Childhood 28; 182, (.953). 20) 金杉：大日耳䔩，5；277，(1899). 21）朌田：千葉医会誈，32；833,(1957). 22) 北

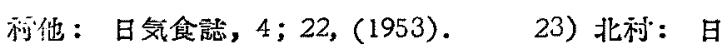
耳等第 57 回総会宿題報告别册 (1956). 24) 北村：

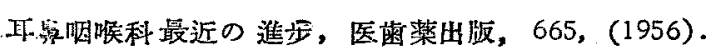
.25) 北村他：Radioisotopes 5；28, (1957). 26) 北河他：耳喉, 29；844,(1957). 27) 北柇他：日

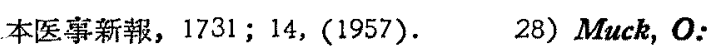

Münch. Med. Wschr. 17; (1900). 29）棠施：

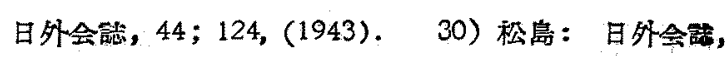

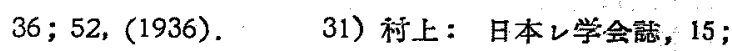

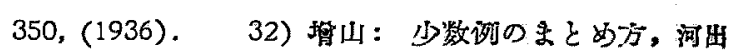
書戻, (1954). 33) Neuss, O.: Zschr. Laryng. $34 ; 307$, (1955). 34) 藇田：日耳鼻, 60;1563, (1957). 35) Rowland, W.: Lancet 104, (1888). 36) Schimansky, E.: Zschr. Laryng. 31 ; 235, (1952). 37) Seifert: Wien. Klin. Wschr. 46; 881, (1889). 38) Schmidthuber, K.: Münch. Med. Wschr. 39; 1406; (1922). 39) Seeger. Th.: Monatschr. f. Ohrenheilk. 70; 582, (1936). 40) Swinburne, J.: Brit. Surg. 27；713，(1940)．41）都贸：日外会 㺊，27，(1927).42) 横須賀：グレンツダビート， 4; 371, (193C). 43) Zack, E.: Wien. Med. Wschr. 47 ; 2293, (1919).

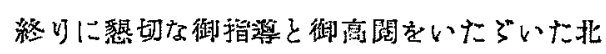
村教授に梁謝すると共に, 種々助言を下さつた 咸田講師及び御助カいたア゙いた教室貝諸氏に感 謝します。

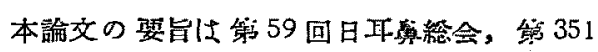

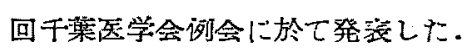

（原稿到着 =昭和 33.9.22 日一急載） 